\title{
MUET Preparation Language Learning Strategies
}

\author{
Yoong Li Kuen and Mohamed Amin Embi \\ (Universiti Kebangsaan Malaysia, Malaysia) \\ doi:10.7575/aiac.alls.v.3n.1p.84
}

\section{Abstract}

The main objective of the study was to examine the English language learning strategies (LLS) used by Lower Six students in secondary schools who are sitting for their MUET test. It analyzed the language learning strategies that students use in order to prepare for the MUET test. Data were collected using a survey questionnaire with 300 students. The instrument used in this study called "MUET Preparation Language Strategy Use Inventory" is an adapted and bilingual questionnaire designed by Cohen, Oxford and Chi (2005) known as Language Strategy Use Inventory. Forty items were analyzed and they comprised of the four skills tested in MUET which is listening, speaking, reading and writing. Data were analyzed by performing frequency analysis. The findings revealed that the listening skill is the most frequently used, while the writing skill is the least frequently used. Only the listening skill has high frequency of use, while the reading, speaking and writing skills fall under the range of moderate frequency of use. There were variations in responses with regard to the use of LLS among Form Six students in secondary schools. The findings had practical implications.

\section{Background and rationale}

The mission of the Ministry of Education (MOE) is to develop a world-class quality education system which will realize the full potential of the individual and fulfill the aspiration of the Malaysian nation. One of the major goals in education is to prepare the nation's human resource for development needs and provide educational opportunities for all Malaysians. Therefore, teachers should educate the students in using suitable strategies so that these strategies will empower them in their lives as students as well as young working adults.

Language learning strategies (LLS) are tools that empower students by enabling them to use "strategies which contribute to the development of the language system which the learner constructs and affect learning directly" (Rubin, 1987, p. 22). Mohamed Amin (2000, p. 12) 
defines LLS as "plans and/ or actions that learners take to enhance the process of language learning". O' Malley and Chamot (1990) define LLS as "the special thoughts or behaviours that individuals use to help them comprehend, learn or retain new information" (p. 1). Learners' beliefs are also taken into account. Different learners have different views as to what promotes effective language learning. Therefore, LLSs can be defined as conscious attempts by the learner to facilitate or improve learning based on personal beliefs about the learning process.

In this era of globalization, English is increasingly important in all areas of education and academic exchange, science and technology, international travel, economics and business, politics and diplomacy, infotainment and the internet. It is this view that has sparked the immediate policy of learning Science and Mathematics in all schools in Malaysia in the year 2003. The then prime minister, Tun Dr Mahathir Mohamad foresaw that if Malaysia were to be a developed country, its citizens need to be proficient and competent in English. Even the Education Act of Malaysia (1996) states that the English Language (EL) is the second most important language.

However, as much as a lot of emphasis is placed on English, it is common knowledge that the standard of the English Language (EL) has declined drastically over the years. Tun Dr. Mahathir stated that learners of English as a second language (ESL) still lack proficiency based on a public examination (Sijil Pelajaran Malaysia, 2003). These students will need to sit for the MUET examination (Malaysian University English Test) and must pass with at least a Band 3 in order to secure a place at a local private or public university or college. An analysis of the Malaysian University English Test (MUET) results indicates that university learners are still weak in English language proficiency (Yoong, 2010).

A number of researchers have shown that good and successful language learners use different strategies to be more self-directed so as to be more proficient (Wenden, 1991). In fact, a number of studies on second language acquisition and its relationship with the language learning strategies have been carried out by O'Malley and Chamot (1990), Oxford (1993) and Rubin (1975). 


\section{Theoretical perspectives}

It has been more than thirty years since research into LLS began in the early 1970s. According to Cohen and Macaro (2007), the arrival of LLS research formed part of a fundamental shift of perspective in thinking about the process of language learning. Until the 1970s, language learning was seen essentially as a psychological phenomenon as was stated by Stern (1983) that developments in cognitive psychology influenced much of the early research on LLS. In most of the research in this area, the primary concern has been on identifying what good language learners report they do to learn a second or foreign language, or, in some cases, are observed doing while learning a second or foreign language (Wenden \& Rubin, 1987). Later focus and findings have developed into wider dimensions such as factors that influence learners.

There are various definitions of LLS. One of the earliest figures, Rubin (1975) defined LLS as the techniques or devices that learners use to acquire second language knowledge, while Stern (1983) described LLS as general order higher approaches to learning which govern the choice of specific techniques. Later definitions of LLS by Chamot (2004) regarded LLS as most part unobservable, though some may be associated with an observable behaviour.

A number of researchers have shown that good and successful language learners use different strategies to be more self-directed so as to be more proficient (Wenden, 1991). Language learning strategies are important because previous researchers (Chamot \& Kupper, 1989; Cohen, 1990) suggested that training students to use LLS could help them become better language learners. Therefore, this study aims to find out whether better Form Six learners in secondary schools use more strategies than others as claimed by previous researchers. (Bremner, 1999; Faizahani, 2003; Mohamed Amin, 1996; Oxford, 1989) In Malaysia, the history of LLS research is fairly new and was pioneered by Mohamed Amin (1996) through his self-report Strategy Questionnaire (SQ) which was divided into three categories, namely classroom language learning strategies, out-of-class language learning strategies and exam language learning strategies.

\section{Methodology}

The main aim of this study is to determine the English language learning strategies (LLS) used by MUET candidates in schools and the frequency of use. The data were collected using survey instruments designed to discover the subjects' English language learning strategies. 
The data were analyzed using statistical procedures in order to examine the subjects' responses on their use of LLS.

The participants constituted a random sample of students from five secondary schools in Melaka. The data were collected from three hundred students $(n=300)$. The age range of the subjects was 18-20 years.

Cohen, Oxford and Chi's (2005) survey instrument known as Language Strategy Use Inventory was adapted and utilized to gather the data from the Lower Six students in the secondary schools. The instrument used in this study is known as the MUET Preparation Language Strategy Use Inventory. It is a bilingual inventory with the Bahasa Malaysia translation done by the National Translation Institute of Malaysia. There were forty items from the instrument that were analyzed and these were divided into four different components based on the skills tested in the MUET test that is listening, speaking, reading and writing. The instrument consists of Likert-scale items (a scale from 1-5) which used a forced-choice format in which subjects were asked to select from one of the following choices: (1) never true of me, (2) usually not true of me, (3) sometimes true of me, (4) usually true of me, and (5) always true of me. In addition, the subjects were required to respond to question items pertaining to demographic information such as gender, Science/Arts streaming and English SPM results. A statistical program, i.e. the SPSS was utilized to process the data. Frequency analysis was performed to examine the learners' responses with respect to their use of LLS.

\section{Findings}

The results of this study are presented in terms of answering the five research questions. To answer RQ 1: "What are the LLS used by Form Six students in schools?" frequencies with respect to listening, speaking, reading and writing were analyzed. Table 1 shows the mean scores and frequency of LLS skills.

\section{Table 1: Mean scores and frequency of LLS skills}

\begin{tabular}{lllcl}
\hline Skills Category & Mean Scores & S.D. & Frequency of Use & Rank of Use \\
\hline Listening & $\mathbf{3 . 5 8 3}$ & .529 & High & 1 \\
Reading & 3.493 & .554 & Moderate & 2 \\
Speaking & 3.323 & .555 & Moderate & 3 \\
Writing & 3.319 & .619 & Moderate & 4 \\
Overall Strategy & 3.418 & .479 & Moderate & \\
\hline
\end{tabular}


To obtain the answer for this question, the mean scores for the four skills of listening, speaking, reading and writing as well as for each individual strategy used by the candidates were calculated. The results in Table 1 shows that the overall strategy use is $\mathrm{M}=3.418, \mathrm{SD}=$ .479 and it indicates that the Lower Six candidates are moderate strategy users. They also reported having moderate to high frequently use of each of the four skills with mean scores ranging between $\mathrm{M}=3.583$ and $\mathrm{M}=3.319$; and with listening skill being the most frequently used, while writing skill is the least frequently used. There is only one skill that is listening which has high frequency of use while reading, speaking and writing skills fall under the range of moderate frequency of use.

An interpretation mean score was used to determine the frequency of LLS use according to the four language skills. The students' responses were categorized into three broader categories namely high, moderate and low frequency of use of language learning strategy. The mean score for each item was tabulated and the frequency of strategy use for each item was determined using the frequency ratings provided in Table 2. These ratings were adapted from Oxford's (1990, p. 336) scale rating for SILL.

Table 2: Frequency ratings for strategy use

\begin{tabular}{lll}
\hline Frequency of Use & Responses & Mean Scores \\
\hline High & ALWAYS TRUE of me & $4.5-5.0$ \\
& USUALLY TRUE of me & $3.5-4.4$ \\
Moderate/ Medium & SOMETIMES TRUE of me & $2.5-3.4$ \\
Low & USUALLY NOT TRUE of me & $1.5-2.4$ \\
& NEVER TRUE of me & $1.0-1.4$ \\
\hline
\end{tabular}

These ratings were adapted from Oxford's (1990, p.336) scale rating for SILL.

To answer RQ 2: "What is the frequency of use according to the listening skill?" frequencies with respect to the items under the listening skill were analyzed. Out of the ten items, seven items fall under the high frequency of use. Table 3 shows the frequency analysis of the items under the listening skill in terms of the rank of use from the highest rank (number 1) to the lowest rank (number 7) in terms of high frequency of use. As can be seen in Table 3, seven items fall under the high frequency of use. It was found that most of the subjects $(63.3 \%$ i.e. $34.3 \%$ usually true and $29 \%$ always true) listen to people who are speaking in English to try to understand what they are saying. Majority of the students ask for clarification if they don't understand it the first time around, of which $41 \%$ and $17.7 \%$ indicated "usually true" and "always true" responses respectively. Almost all of the respondents, with $37.3 \%$ usually true 
and $21.3 \%$ always true ask speakers to repeat what they said if it wasn't clear to them. The results also revealed that $57 \%$ (37\% usually true and $20 \%$ always true) of students try to understand what they hear without translating it word-for-word.

Table 3: Frequency of use according to the listening skill

\begin{tabular}{|c|c|c|c|c|c|c|}
\hline No & Question Items & $\begin{array}{l}\text { Never } \\
\text { true }\end{array}$ & $\begin{array}{l}\text { Usually } \\
\text { not true }\end{array}$ & $\begin{array}{l}\text { Sometimes } \\
\text { true }\end{array}$ & $\begin{array}{l}\text { Usually } \\
\text { True }\end{array}$ & $\begin{array}{c}\text { Always } \\
\text { True }\end{array}$ \\
\hline$\overline{\mathrm{A} 2}$ & $\begin{array}{l}\text { Listening to people who are speaking in } \\
\text { English to try to understand what they are } \\
\text { saying. }\end{array}$ & $.7 \%$ & $4.0 \%$ & $32 \%$ & $34.3 \%$ & $29 \%$ \\
\hline A9 & $\begin{array}{l}\text { Ask for clarification if I don't understand } \\
\text { it the first time around. }\end{array}$ & $1.3 \%$ & $9.3 \%$ & $30.7 \%$ & $41.0 \%$ & $17.7 \%$ \\
\hline A8 & $\begin{array}{l}\text { Ask speakers to repeat what they said if it } \\
\text { wasn't clear to me. }\end{array}$ & $3.3 \%$ & $10 \%$ & $28 \%$ & $37.3 \%$ & $21.3 \%$ \\
\hline A7 & $\begin{array}{l}\text { Try to understand what I hear without } \\
\text { translating it word-for-word. }\end{array}$ & $2.3 \%$ & $9.3 \%$ & $31.3 \%$ & $37 \%$ & $20 \%$ \\
\hline A1 & $\begin{array}{l}\text { Listen to talk shows on the radio, watch } \\
\text { TV shows, or see movies in the English } \\
\text { language. }\end{array}$ & $1.7 \%$ & $5.3 \%$ & $45 \%$ & $24.7 \%$ & $23.3 \%$ \\
\hline A10 & $\begin{array}{l}\text { Draw on my general background } \\
\text { knowledge to get the main idea. }\end{array}$ & $1.3 \%$ & $7.7 \%$ & $40.3 \%$ & $31.3 \%$ & $19.3 \%$ \\
\hline A4 & $\begin{array}{l}\text { Pay special attention to specific aspects of } \\
\text { the language (e.g. the way the speaker } \\
\text { pronounces certain sounds). }\end{array}$ & $1.7 \%$ & $12.7 \%$ & $37 \%$ & $29.7 \%$ & $19.0 \%$ \\
\hline
\end{tabular}

It was found that many of the subjects (48\% i.e. $24.7 \%$ usually true and $23.3 \%$ always true) listen to talk shows on the radio, watch TV shows, or see movies in the English language. Many of the students draw on their general background knowledge to get the main idea, of which $31.3 \%$ and $19.3 \%$ indicated "usually true" and "always true" responses respectively. Nearly half of the respondents, with $29.7 \%$ usually true and 19\% always true pay special attention to specific aspects of the language (e.g. the way the speaker pronounces certain sounds).

To answer RQ 3: "What is the frequency of use according to the speaking skill?" frequencies with respect to the items under the speaking skill were analyzed. Out of the ten items, three items fall under the high frequency of use. Table 4 shows the frequency analysis of the items under the speaking skill in terms of the rank of use from the highest rank (number 1) to the lowest rank (number 3) in terms of high frequency of use. As can be seen in Table 4, only three items fall under the high frequency of use. The data revealed that $58 \%$ of the subjects encourage others to correct errors in their speaking, with $33.3 \%$ usually true and $24.7 \%$ always true. More than half of the participants (56\%) indicated that they ask for help from their conversational partner, specifically $39.7 \%$ usually true and $16.3 \%$ always true. Majority 
of the respondents, with $34 \%$ usually true and $17.7 \%$ always true plan out in advance what they want to say.

Table 4: Frequency of use according to the speaking skill

\begin{tabular}{lllllll}
\hline No & Question Items & $\begin{array}{l}\text { Never } \\
\text { true }\end{array}$ & $\begin{array}{l}\text { Usually } \\
\text { not true }\end{array}$ & $\begin{array}{l}\text { Sometimes } \\
\text { true }\end{array}$ & $\begin{array}{l}\text { Usually } \\
\text { True }\end{array}$ & $\begin{array}{c}\text { Always } \\
\text { True }\end{array}$ \\
\hline B8 & $\begin{array}{l}\text { Encourage others to correct errors in my } \\
\text { speaking }\end{array}$ & $3.0 \%$ & $10.3 \%$ & $28.7 \%$ & $33.3 \%$ & $24.7 \%$ \\
B9 & $\begin{array}{l}\text { Ask for help from my conversational } \\
\text { partner }\end{array}$ & $7 \%$ & $12.0 \%$ & $31.3 \%$ & $39.7 \%$ & $16.3 \%$ \\
B5 & Plan out in advance what I want to say & $3.0 \%$ & $8.7 \%$ & $36.7 \%$ & $34.0 \%$ & $17.7 \%$ \\
\hline
\end{tabular}

To answer RQ 4: "What is the frequency of use according to the reading skill?" frequencies with respect to the items under the reading skill were analyzed. Out of the ten items, six items fall under the high frequency of use. Table 5 shows the frequency analysis of the items under the reading skill in terms of the rank of use from the highest rank (number 1) to the lowest rank (number 6) in terms of high frequency of use.

Table 5: Frequency of use according to the reading skill

\begin{tabular}{|c|c|c|c|c|c|c|}
\hline No & Question Items & $\begin{array}{l}\text { Never } \\
\text { true }\end{array}$ & $\begin{array}{l}\text { Usually } \\
\text { not true }\end{array}$ & $\begin{array}{l}\text { Sometimes } \\
\text { true }\end{array}$ & $\begin{array}{l}\text { Usually } \\
\text { True }\end{array}$ & $\begin{array}{c}\text { Always } \\
\text { True }\end{array}$ \\
\hline $\mathrm{C} 5$ & $\begin{array}{l}\text { Read a story or dialogue several times } \\
\text { until I understand it }\end{array}$ & $2.3 \%$ & $8.3 \%$ & $29 \%$ & $34.3 \%$ & $26 \%$ \\
\hline C9 & $\begin{array}{l}\text { Guess the approximate meaning by using } \\
\text { clues from the context of the reading } \\
\text { material. }\end{array}$ & $.3 \%$ & $6.3 \%$ & $32 \%$ & $44 \%$ & $17.3 \%$ \\
\hline $\mathrm{C} 10$ & $\begin{array}{l}\text { Use a dictionary to get a detailed sense of } \\
\text { what individual words mean }\end{array}$ & $4.3 \%$ & $10.7 \%$ & $31 \%$ & $30.3 \%$ & $23.7 \%$ \\
\hline $\mathrm{C} 3$ & $\begin{array}{l}\text { Find reading material that is at or near my } \\
\text { level }\end{array}$ & $1.3 \%$ & $11.3 \%$ & $31.7 \%$ & $40.3 \%$ & $15.3 \%$ \\
\hline $\mathrm{C} 4$ & $\begin{array}{l}\text { Skim any academic text first to get the } \\
\text { main idea and then go back and read it } \\
\text { more carefully. }\end{array}$ & $5.0 \%$ & $10.7 \%$ & $29.7 \%$ & $35 \%$ & $19.7 \%$ \\
\hline $\mathrm{C} 2$ & $\begin{array}{l}\text { Try to find things to read for pleasure in } \\
\text { the target language. }\end{array}$ & $1.7 \%$ & $12.7 \%$ & $35 \%$ & $34 \%$ & $16.7 \%$ \\
\hline
\end{tabular}

As can be seen in Table 5, six items fall under the high frequency of use. It was found that most of the subjects $(60.3 \%$ i.e. $34.3 \%$ usually true and $26 \%$ always true) read a story or dialogue several times until they understand it. Majority of the students guess the approximate meaning by using clues from the context of the reading material, of which $44 \%$ and $17.3 \%$ indicated"usually true" and "always true" responses respectively. Almost all of the respondents, with $30.3 \%$ usually true and $23.7 \%$ always true use a dictionary to get a detailed sense of what individual words mean. The results also revealed that $55.6 \%(40.3 \%$ 
usually true and $15.3 \%$ always true) of students find reading material that is at or near their level. It was found that many of the subjects (54.7\% i.e. $35 \%$ usually true and $19.7 \%$ always true) skim any academic text first to get the main idea and then go back and read it more carefully. Many of the students try to find things to read for pleasure in the target language, of which $34 \%$ and $16.7 \%$ indicated "usually true" and "always true" responses respectively.

To answer RQ 5: "What is the frequency of use according to the writing skill?" frequencies with respect to the items under the writing skill were analyzed. Out of the ten items, three items fall under the high frequency of use. Table 6 shows the frequency analysis of the items under the writing skill in terms of the rank of use from the highest rank (number 1) to the lowest rank (number 3) in terms of high frequency of use.

Table 6: Frequency of use according to the writing skill

\begin{tabular}{|c|c|c|c|c|c|c|}
\hline No & Question Items & $\begin{array}{l}\text { Never } \\
\text { true }\end{array}$ & $\begin{array}{l}\text { Usually } \\
\text { not true }\end{array}$ & $\begin{array}{l}\text { Sometimes } \\
\text { true }\end{array}$ & $\begin{array}{l}\text { Usually } \\
\text { True }\end{array}$ & $\begin{array}{c}\text { Always } \\
\text { True }\end{array}$ \\
\hline D5 & $\begin{array}{l}\text { Find a different way to express the idea } \\
\text { when I don't know the correct expression } \\
\text { (e.g., use a synonym or describe the } \\
\text { idea). }\end{array}$ & $2.0 \%$ & $10.3 \%$ & $31 \%$ & $41.7 \%$ & $15 \%$ \\
\hline D6 & $\begin{array}{l}\text { Review what I have already written before } \\
\text { continuing to write more. }\end{array}$ & $1.3 \%$ & $12.7 \%$ & $31.0 \%$ & $40.3 \%$ & $14.7 \%$ \\
\hline D7 & $\begin{array}{l}\text { Use reference materials such as a glossary, } \\
\text { a dictionary, or a thesaurus to help find or } \\
\text { verify words in the target language. }\end{array}$ & $3.0 \%$ & $17 \%$ & $26 \%$ & $33.7 \%$ & $20.3 \%$ \\
\hline
\end{tabular}

From Table 6, only three items fall under the high frequency of use. The data revealed that $56.7 \%$ of the subjects find a different way to express the idea when they don't know the correct expression (e.g., use a synonym or describe the idea), with $41.7 \%$ usually true and $15 \%$ always true. More than half of the participants $(55 \%)$ indicated that they review what they have already written before continuing to write more, specifically $40.3 \%$ usually true and $14.7 \%$ always true. Majority of the respondents, with $33.7 \%$ usually true and $20.3 \%$ always true use reference materials such as a glossary, a dictionary, or a thesaurus to help find or verify words in the target language.

\section{Discussion and conclusion}

It can be seen that there were different learners' responses towards the use of LLS in preparing for the MUET test. With regard to the use of the individual strategy, out of 40 items, the descriptive statistics indicated that 19 individual strategies comprising of listening, speaking, reading and writing were high frequently used with the mean scores ranging from 
3.51 to 3.87 . The other 21 individual strategies were moderately used with the mean scores ranging from 2.95 to 3.47 . Out of 19 high frequency use of individual strategy, 7 listening skills, 6 reading skills, 3 speaking skills and 3 writing skills were most frequently used. However, there were no items that fall under the range of low frequency of use in this study.

Among the listening strategies that fall under the range of average frequency of use were "practice sounds in the target language that are very different from sounds in my own language to become comfortable with them", "try to predict what the other person is going to say based on what has been said so far" and "listen for key words that seem to carry the bulk of the meaning". This shows that the majority of students do not have an understanding of phonetics and they do not know how to listen for key words. These students do not know how to use LLS to help them become more competent users of the language. They may not even be aware of the existence of language learning strategies that can empower them.

As the primary aim of ESL syllabus in schools is to enable learners to achieve proficiency and competency at the highest level, it is proposed that training in the use of LLS should be included in the ESL syllabus. According to Wenden (1991), by focusing on learner-centered practices, teachers would change the learners to become better learners. These learners would benefit from instructions in developing LLS by becoming more competent users of the language. It is hoped that learners would be able to identify, choose, adopt and practice these strategies so as to be able to participate effectively and move towards learner autonomy. In other words, the learner will learn to take full responsibility for their learning (Cook, 2001; Radha, 1996). In a secondary school context, these findings could be considered during the review of the present ESL syllabus. 


\section{References}

Bremner, S. (1999). Language Learning Strategies and Language Proficiency: Investigating the Relationship in Hong Kong. Canadian Modern Language Review, 55 (4): 490-514.

Chamot, A. U. (2004). Issues in Language Learning Strategy Research and Teaching. Electronic Journal of Foreign Language Teaching, 1 (1) 14-26. Retrieved from http://EFlt.Nus.Edu.Sg/V1n12004/Chamot.Pdf

Chamot, A. U. \& Kupper, Lisa. (1989). Learning Strategies in Foreign Language Instruction. Foreign Language Annals, 22 (1): 13-24.

Cohen, A. (Ed.) (1990). Language Learning: Insights for Learners, Teachers and Researchers. Massachusetts: Heinle \& Heinle Publishers.

Cohen, A. (1998). Strategies in Learning and Using a Second Language. London: Longman.

Cohen, A. \& Macaro, E. ( Eds. ) (2007). Language Learner Strategies. UK, Oxford: University Press.

Cohen, A., Oxford, R. \& Chi, J.L. (2005) Language strategy use inventory. Retrieved from http://www.carla.umn.edu/about/profiles/cohen.html

Cook, V. (2001). Second Language Learning and Language Teaching. Great Britain: Oxford University Press.

Education Act (1996). Government of Malaysia. Kuala Lumpur: Government Printers.

Faizahani, R. (2003). Strategies Employed by Good and Weak English Learners and Factors Affecting the Choice of Strategies. Unpublished master thesis, Universiti Kebangsaan Malaysia, Bangi.

Mohamed Amin Embi (1996). Language Learning Strategies Employed by Secondary School Students Learning English as a Foreign Language in Malaysia. Unpublished Ph.D thesis, University of Leeds, UK.

O' Malley, J. M. \& Chamot, A. U. (1990). Learning Strategies in Second Language Acquisition. Sydney: Cambridge University Press.

Oxford, R. (1989). Use of Language Learning Strategies: A Synthesis of Studies with Implications for Strategy Training. System, 17 (2): 235-47.

Oxford, R. (1990). Language Learning Strategies: What Every Teacher Should Know. Massachusetts: Heinle\& Heinle Publishers.

Oxford, R. (1993). Instructional Implications of Gender Differences In Second/Foreign Language. Applied Language Learning, 4 (1-2): 65-94.

Radha Nambiar (1996). Language Learning Strategies of Six Malaysian ESL Learners when Performing Selected Language Activities. Unpublished master thesis. Faculty of Language Studies. Universiti Kebangsaan Malaysia.

Rubin, J. (1975). What the 'good language learner' can teach us? TESOL Quarterly, 9 (1), 41-51.

Stern, H. (1983). Fundamental Concepts of Language Teaching. Oxford: OUP.

Yoong Lee Kuan (2010). English Langugae Learning Strategies used by Form Six Students in Secondary Schools. Unpublished Master Thesis, School of Education, Universiti Kebangsaan Malaysia.

Wenden, A. (1991). Learner Strategies for Learner Autonomy. UK: Prentice Hall.

Wenden, A. \& J. Rubin (Eds.). (1987). Learner Strategies in Language Learning. London: Prentice- Hall International. 